
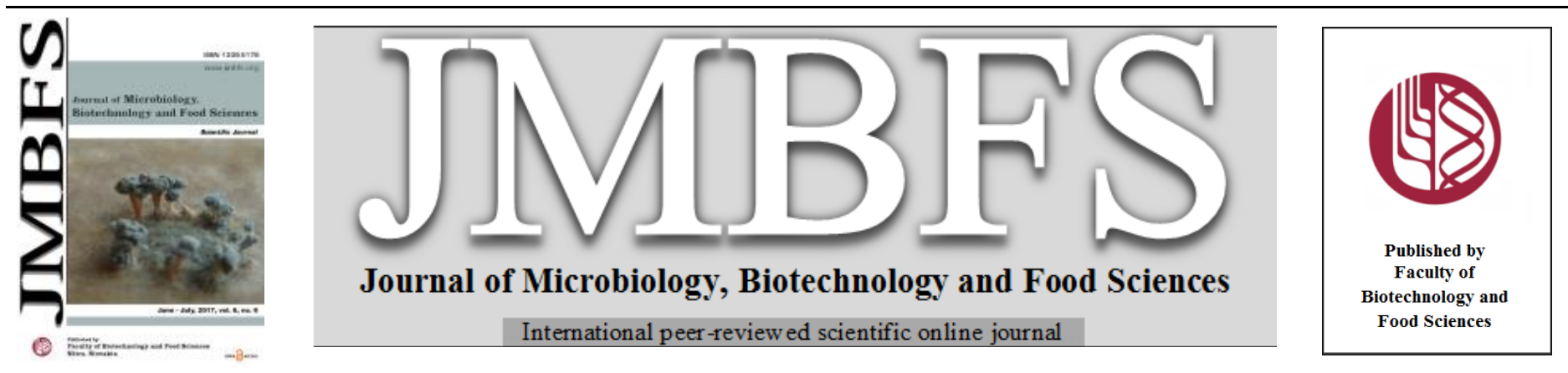

\title{
DIVERSITY OF BACTERIA DURING FERMENTATION OF LIMABEAN INTO DADDAWA
}

\section{Elizabeth Oluremi Farinde ${ }^{*}$, Sumbo Henrietta Abiose ${ }^{2}$, and Hezekiah Adekanmi. Adeniran ${ }^{2}$}

\author{
Address(es): Dr. Elizabeth Farinde, \\ ${ }^{1}$ Product Development Programme, Institute of Agricultural Research and Training, PMB 5029, Ibadan, Nigeria. Phone: +2348075459882. \\ ${ }^{2}$ Department of Food Science and Technology, Obafemi Awolowo university, Ile-Ife, Nigeria.
}

*Corresponding author: osekinat@yahoo.co.uk

doi: $10.15414 /$ jmbfs.2017.6.6.1228-1232

\section{ARTICLE INFO}

Received 17. 10. 2016

Revised 16. 3. 2017

Accepted 22. 3. 2017

Published 1. 6. 2017

Regular article

OPEN $\partial_{\text {ACCESS }}$

\begin{abstract}
The diversity and succession of bacteria during the natural fermentation of lima bean (Phaseolus lunatus) to produce daddawa (a fermented condiment) was studied using molecular method (16SrRNA gene analysis) with a view to develop a framework for production of daddawa of consistence quality with starter culture of Bacillus species. Lima bean was fermented for $72 \mathrm{~h}$, during which isolation of bacteria and extraction of DNA were carried out. The extracted DNA of the bacterial isolates was tested for quality using agarose gel electrophoresis. The results of the 16SrRNA gene analysis were matched with the existing similar sequences in data base. Twenty six (26) presumptive isolates of Bacillus obtained at $24 \mathrm{~h}$ interval during the natural fermentation process were identified. The result of the ratio of absorbances of the extracted DNA at 260 and $280 \mathrm{~nm}$ showed that $73 \%$ of the isolates had pure DNA while the result of the gel electrophoresis showed well defined bands of the amplicons for the isolates. The BLAST result identified the isolates as Bacillus amyloliquefaciens, B. subtilis, B. pumilus, B. cereus and B. anthrasis with B. subtilis been the most predominant. Bacillus amyloliquefaciens, B. subtilis and B. pumilus occurred through-out the fermentation process. The study established the identity of the important Bacillus species involved in fermentation of lima bean into daddawa using molecular technique. These major Bacillus species could further be tested and developed as potential starters for improved production of daddawa from lima bean.
\end{abstract}

Keywords: Limabean, daddawa, Fermentation, Bacillus, 16SrRNA gene analysis

\section{INTRODUCTION}

Daddawa also known as iru, among the Yorubas in South-west Nigeria, is a popular condiment used as taste and flavour enhancer in soup and dishes in Africa. Daddawa is traditionally produced from locust beans (Parkia biglobossa) seeds. The tree is a leguminous plant found in the Savannah region of Africa, South East Asia and South America (Egwim et. al., 2013). The tree is a perennia plant with pods ranging from pink, brown to dark brown, when matured. Nutritionally, African locust bean is an outstanding source of plant protein (Elemo et al., 2011). However, locust bean trees are going into extinction from their natural habitat because they are not cultivated. Lima bean (Phaseolus lunatus) is an under-utilized legumes, whose seeds are good source of protein, dietary fibre, potassium, iron, copper, phosphorous, magnesium and thiamin (WHFoods, 2010). Previous study has shown that Lima bean could be used in production of daddawa (Farinde et al., 2011).

Biochemical method has been the conventional method for identification of isolates in fermentation process to produce daddawa (Abiose et al., 1986; Barber et al., 1988; Achi, 1992; Barimalaa et al., 1994; Omafuvbe et al., 2000, 2002; Farinde et al., 2011). This method may not account for minor microbial populations, stressed or injured cells that may be present in low number (Fleet, 1999). The biochemical method may not give a complete representation of food microbial community (Kesmen et al., 2012). In the last decades, interests in microbial ecology have increased due to advances in molecular biology such as advent of polymerase chain reaction and DNA sequencing (Cocolin and Ercolini, 2009). Succession of microorganisms involved in fermentation of African locust bean seeds using culture dependent techniques have been studied by various researchers (Abiose et al.,1986; Achi, 1992; Omafuvbe et al., 2004; Adelekan and Nwadiuto,2012; Adewunmi et al., 2013) and it has been shown that the major microorganisms involved in the fermentation process are the Bacillus species. Molecular genotyping techniques are considered to be effective and rapid tool for identification and characterization of Bacillus (Morten et al., 2000; Miambi et al., 2003).

These techniques include restriction fragment length polymorphism (RFLP) for the grouping and typing of the isolates at species level (Joung and Cote, 2002), 16SrDNA sequencing for the description of phylogenetic relationships (Ash et al., 1992) and pulse field gel electrophoresis (PFGE) for the differentiation of isolates at strain level (Liu and Chen, 1997; Mendo et al., 2000). Identification and succession of microorganisms involved in fermentation of Lima bean to produce daddawa using molecular method is yet to be documented. The present study therefore employed molecular method to identify the predominant bacteria during natural fermentation of Lima bean to produce daddawa.

\section{MATERIALS AND METHODS}

Matured dried lima bean seeds were purchased at Ita-ogbolu, Ondo State, Nigeria. Calabashes, cooking pots, washing bowls and sample dishes were obtained from a local market in Ibadan, Nigeria. The media used were obtained from Oxoid (UK) and LAB M (UK). Primers and reagents for molecular analyses were obtained from Inqaba Biotechnology, South Africa.

\section{Lima bean fermentation}

Lima bean fermentation was carried out according to the method used by Farinde et al. (2014). Lima bean seeds were roasted, dehulled and cooked for 40 min. The cooked beans were drained and poured while still warm into clean calabash lined with clean banana leaves, covered with banana leaves before covering with another calabash. One calabash was prepared for each fermentation stage. The calabashes with their content were placed in an incubator for fermentation to take place at $35^{\circ} \mathrm{C} \pm 2{ }^{\circ} \mathrm{C}$ for $72 \mathrm{~h}$. Sampling of the Lima beans under fermentation was carried out at $24 \mathrm{~h}$ intervals in triplicates.

\section{Microbial analysis}

Total viable count (TVC) was determined using the method described by Abiose et al. (1986) and Omafuvbe et al. (2000). Aliquot $(1.0 \mathrm{ml})$ of appropriately diluted sample was plated in triplicates on nutrient agar (NA) plates. The plates were then incubated aerobically at $35^{\circ} \mathrm{C} \pm 2{ }^{\circ} \mathrm{C}$ for $24 \mathrm{~h}$. Colonies were counted and expressed as colony forming unit per gram ( $\mathrm{cfu} \mathrm{g}^{-1}$ ) of the sample. Representative colonies were streaked repeatedly to obtain pure isolates. Preliminary identification of the bacterial isolates was based on cultural characteristics, Gram staining reactions (Harrigan and McCance, 1976; Harrigan, 1998). 


\section{Molecular identification of Bacterial isolate}

The isolated bacteria were identified using the method described by Adelekan and Nwadiuto (2012). The experiments were carried out at National Center for Genetic Resources and Biotechnology (NACGRAB) and International Institute of Tropical Agriculture (IITA), both in Ibadan, Nigeria. The method involves DNA extraction, PCR amplification and DNA sequencing.

\section{DNA extraction and quality verification}

DNA was extracted using DNA extraction kit. ZR Fungal/Bacterial DNA MiniPrep ${ }^{\mathrm{TM}}$ protocol (ZYMO Research) following manufacturer's instructions. Modified method of Adelekan and Nwadiuto (2012) was used. Lysing of bacterial cells to bring out the DNA was done using bashing beads and lysis solution supplied in the DNA extraction kit instead of the method of freezing thawing cycles used by Adelekan and Nwadiuto (2012). The extracted DNA was verified for purity and quality using quantitative and qualitative methods Quantitative method was carried out using Nano drop spectrophotometer. DNA sample $(1 \mu \mathrm{l})$ was loaded using micro pipette into the Nano drop spectrophotometer and the absorbances of the samples were read at 260 and 280 nanometer. The concentration of the extracted DNA and the ratio of the absorbance were automatically generated and displayed on the equipment. The concentration must not be less than $10 \mathrm{ng} / \mu 1$ (Leninger, 1975; Biobank, 2004) The ratio of the absorbance is also important during Polymerase chain reaction (PCR). It must be between 1.8 and 2.2 for optimum DNA concentration of high purity (Leninger, 1975; Brown, 1993; Biobank, 2004).

Qualitative method was carried out using agarose gel electrophoresis. Agarose (1\%) was prepared in Trisboric EDTA buffer (TBE) and melted in a microwave and cooled to $50{ }^{\circ} \mathrm{C}$. The molten agarose was stained with Gel Green $(20 \mu \mathrm{l})$. Ge Green fluoresce under UV light. Stained agarose was poured into gel caster in which comb had been placed at one end. The gel was allowed to solidify. The solid gel was placed in electrophoresis tank containing TBE buffer and the comb was gently removed. DNA $(1 \mu \mathrm{l})$ was mixed with loading dye $(7 \mu \mathrm{l})$ and loaded into wells created by the comb. The electrophoresis was allowed to run at 130 volts for about 1hour 30 min during which DNA molecules migrated through the agarose gel in the buffer.

\section{Photographing the gel}

The gel was removed from the electrophoresis tank and placed under U.V light in a documentation unit and viewed using a protective eye glasses. A Polaroid camera was placed over the documentation box and the gel was photographed. Sharp bands indicated quality DNA.

\section{Amplification of DNA by polymerase chain reaction}

Specific region of $16 \mathrm{SrRNA}$ gene of isolated DNA was amplified by reacting the cell solution (template DNA) $(1 \mu \mathrm{l})$ with polymerase chain reaction (PCR) master mix $(8 \mu \mathrm{l})$, primers $(1 \mu \mathrm{l})$ and nuclease free water $(6 \mu \mathrm{l})$ and running the reaction cycles in a PCR thermocycler machine (Lexus Gradient -Eppendorff AG). The primers used in this study were universal primers, synthesized commercially by Inqaba Biotechnology, South Africa. The pair of primer consists of forward primer F 27 having nucleotide sequence AGAGTTTGATC(A/C)TGGCTCAG and reverse primer $\mathrm{R} 1492$ having nucleotide sequence TACGG(C/T)TACCTTGTTACGACTT. Control tube (PCR reaction mixture minus template DNA) was also set along with the reaction tubes. The reaction was allowed to run 35 cycles at conditions of $94{ }^{\circ} \mathrm{C}$ for 3 minutes (Initial Denaturation), $94{ }^{\circ} \mathrm{C}$ for 1 minute (Final Denaturation), $55^{\circ} \mathrm{C}$ for 30 seconds (Annealing), $72{ }^{\circ} \mathrm{C}$ for 2 minute (Extension) and $72{ }^{\circ} \mathrm{C}$ for 4 minutes (Final extension).

All PCR products were verified using 1\% agarose gel electrophoresis as previously described. The samples were loaded along with Themo- scientific Gene ruler/ ladder (1 kbp)

\section{DNA sequencing and Identification of isolates}

Big Dye Terminator Cycle sequencing kit protocol was used for sequencing the amplicons and the gel was run on 3130 X 1.16 capillaries genetic analyzer from Applied Biosystems. The resultant sequences were submitted to Data base (Genbank, Germany) of National center for biotechnology Information (NCBI), the sequences were given accession numbers. The sequences were then matched with existing data in Data base using the Basic local alignment search tool (BLAST) algorithm. BLAST allows alignment of search sequence to thousands of different sequences in the data base (Altschul et al., 1997). Species which had less than $90 \%$ sequence identity with known representative sequence in data base were classified as unknown species and sequences with more than $90 \%$ sequence identity were classified as known species.

\section{RESULTS AND DISCUSSION}

\section{Microbial Counts during Natural Fermentation of Lima Bean to Produce} Daddawa

The result of the Total viable count of microorganisms during natural fermentation of Lima bean to produce daddawa is shown in Figure 1.Total viable count increased from $4.65 \log \mathrm{cfu} \mathrm{g}^{-1}$ at $0 \mathrm{~h}$ to $7.15 \log \mathrm{cfu} \mathrm{g}^{-1}$ at $24 \mathrm{~h}$, reached its peak (logarithmic phase) at $48 \mathrm{~h}$ of fermentation (8.08 $\log \mathrm{cfu} \mathrm{g}^{-1}$ ) after which the count dropped to $7.40 \log$ cfu $\mathrm{g}^{-1}$ at $72 \mathrm{~h}$ of fermentation. Similar trend of an initial increase in total viable bacteria count between 0 and $48 \mathrm{~h}$ of fermentation and subsequent drop in the count at $72 \mathrm{~h}$ of fermentation during production of daddawa have been reported (Abiose et al., 1986; Omafuvbe et al., 2000; Omafuvbe et al., 2002; Enujuigba et al. 2008; Fadahunsi and Olubunmi, 2010). Increase in the total count at initial fermentation phase is probably due to availability of nutrients in form of carbon and nitrogen sources.

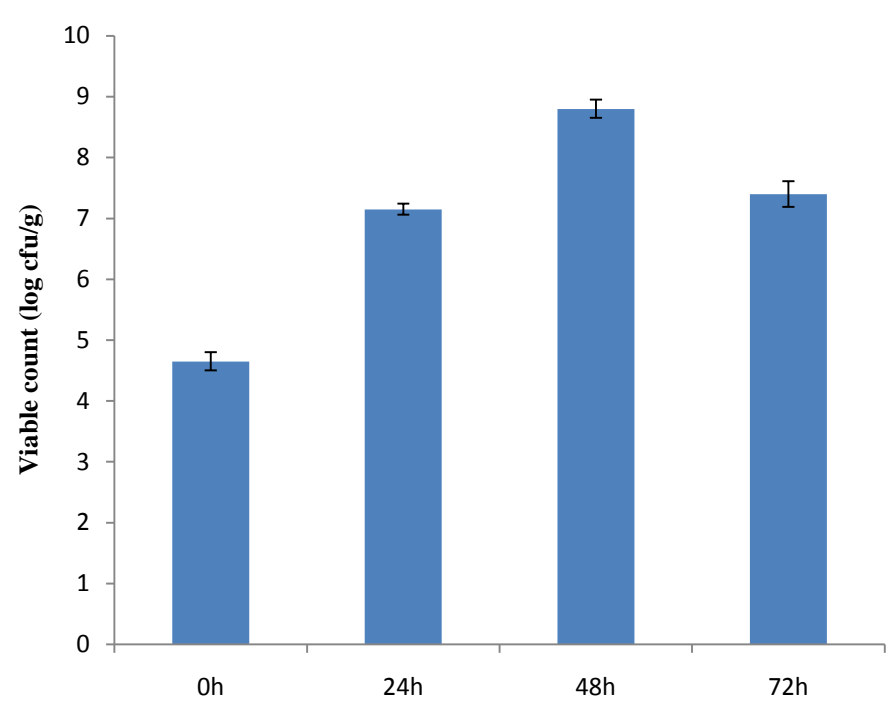

Figure 1Total Viable Count of Microorganisms during Natural Fermentation of lima bean

Lima bean has been reported to have these nutrients in good quantities (Yellavila et al., 2015). The drop in TVC after $48 \mathrm{~h}$ was probably due to depletion of nutrients and accumulation of metabolites. Among the likely metabolites of protein hydrolysis are short peptides and ammoniacal compounds which gave the product its desired flavor. These metabolites were likely more than the metabolites produced from hydrolysis of fat and carbohydrates present in the lima beans. The possible effect of these metabolites is the alkaline $\mathrm{pH}$ values which the microorganisms might possibly be able to tolerate up to $48 \mathrm{~h}$ of fermentation, after which some of the microorganisms may find the increased alkaline environment unfavorable for their growth and proliferation and so the total number of microorganisms declined.

\section{Preliminary identification of bacterial isolates}

Bacteria isolated from natural fermentation of lima bean to produce daddawa are shown in Table 1. The isolates were Gram positive, rods, catalase positive and spore formers. These characteristics allowed preliminary identification of Bacillus (Harrigan and MacCance, 1976; Harrigan, 1998). Bacterial isolates $3,9,19$ and 23 had rhizoid shape, isolates 7,13,16,18 and 20 had circular shape while the rest of the bacterial isolates $(1,2,4,5,6,8,10,11,12,14,15,17,21$, 22,24, 25 and 26) had irregular shape on agar plate. Similar preliminary phenotypic identification of bacterial isolates from iru, afitirin and sonru as belonging to genus Bacillus was reported by Azokpota et al. (2007). This preliminary identification which showed the bacterial isolates as Bacillus was used to search for the appropriate primers for the molecular identification of bacteria isolates. 
Table 1Preliminary identification of Bacterial Isolates from Natural Fermentation of Lima Bean to Produce Daddawa

\begin{tabular}{|c|c|c|c|c|c|}
\hline $\begin{array}{l}\text { Isolate } \\
\text { number }\end{array}$ & $\begin{array}{c}\text { Appearance on agar } \\
\text { plate }\end{array}$ & Shape & Gram's reaction & Catalase reaction & $\begin{array}{c}\text { Presence of } \\
\text { spore }\end{array}$ \\
\hline 1 & Irregular & Rod & $+\mathrm{ve}$ & $+\mathrm{ve}$ & $+\mathrm{ve}$ \\
\hline 2 & Irregular & Rod & $+\mathrm{ve}$ & $+\mathrm{ve}$ & $+\mathrm{ve}$ \\
\hline 3 & Rhizoid & Rod & $+\mathrm{ve}$ & $+\mathrm{ve}$ & $+\mathrm{ve}$ \\
\hline 4 & Irregular & Rod & $+\mathrm{ve}$ & $+\mathrm{ve}$ & $+\mathrm{ve}$ \\
\hline 5 & Irregular & Rod & $+\mathrm{ve}$ & $+\mathrm{ve}$ & $+\mathrm{ve}$ \\
\hline 6 & Irregular & Rod & $+\mathrm{ve}$ & $+\mathrm{ve}$ & $+\mathrm{ve}$ \\
\hline 7 & circular & Rod & $+\mathrm{ve}$ & $+\mathrm{ve}$ & $+\mathrm{ve}$ \\
\hline 8 & Irregular & Rod & $+\mathrm{ve}$ & $+\mathrm{ve}$ & $+\mathrm{ve}$ \\
\hline 9 & Rhizoid & Rod & $+\mathrm{ve}$ & $+\mathrm{ve}$ & $+\mathrm{ve}$ \\
\hline 10 & Irregular & Rod & $+\mathrm{ve}$ & $+\mathrm{ve}$ & $+\mathrm{ve}$ \\
\hline 11 & Irregular & Rod & $+\mathrm{ve}$ & $+\mathrm{ve}$ & $+\mathrm{ve}$ \\
\hline 12 & Irregular & Rod & $+\mathrm{ve}$ & $+\mathrm{ve}$ & $+\mathrm{ve}$ \\
\hline 13 & Circular & Rod & $+\mathrm{ve}$ & $+\mathrm{ve}$ & $+\mathrm{ve}$ \\
\hline 14 & Irregular & Rod & $+\mathrm{ve}$ & $+\mathrm{ve}$ & $+\mathrm{ve}$ \\
\hline 15 & Circular & Rod & $+\mathrm{ve}$ & $+\mathrm{ve}$ & $+\mathrm{ve}$ \\
\hline 16 & Circular & Rod & $+\mathrm{ve}$ & $+\mathrm{ve}$ & $+\mathrm{ve}$ \\
\hline 17 & Irregular & Rod & $+\mathrm{ve}$ & $+\mathrm{ve}$ & $+\mathrm{ve}$ \\
\hline 18 & Circular & Rod & $+\mathrm{ve}$ & $+\mathrm{ve}$ & $+\mathrm{ve}$ \\
\hline 19 & Rhizoid & Rod & $+\mathrm{ve}$ & $+\mathrm{ve}$ & $+\mathrm{ve}$ \\
\hline 20 & Circular & Rod & $+\mathrm{ve}$ & $+\mathrm{ve}$ & $+\mathrm{ve}$ \\
\hline 21 & Irregular & Rod & $+v e$ & $+\mathrm{ve}$ & $+\mathrm{ve}$ \\
\hline 22 & Irregular & Rod & $+\mathrm{ve}$ & $+\mathrm{ve}$ & $+\mathrm{ve}$ \\
\hline 23 & Rhizoid & Rod & $+\mathrm{ve}$ & $+\mathrm{ve}$ & $+\mathrm{ve}$ \\
\hline 24 & Circular & Rod & $+\mathrm{ve}$ & $+\mathrm{ve}$ & $+\mathrm{ve}$ \\
\hline 25 & Irregular & Rod & $+\mathrm{ve}$ & $+\mathrm{ve}$ & $+\mathrm{ve}$ \\
\hline 26 & Irregular & Rod & $+\mathrm{ve}$ & $+\mathrm{ve}$ & $+\mathrm{ve}$ \\
\hline
\end{tabular}

\section{Sequencing and BLAST result}

Forward primer $27 \mathrm{~F}$ and reverse primer $1492 \mathrm{R}$ were used to amplify the 16SrRNA gene of each of the bacterial isolates which resulted in well defined amplicons. When the amplicons were sequenced, the base sequences ranged from 911 in isolate number 8 to 1199 base sequence in isolate number 9 (Table 2).

When the sequences were matched with already existing similar sequences in Gene Bank Data base, all the isolates have their identity between 94 and $98 \%$ as shown in Table 2. Spore forming Bacillus species were identified as the major bacteria present during the fermentation process. Four isolates (isolates 12, 13, 15 and 24) did not match any identity. The identified isolates fell into 5 species of Bacillus (Table 3).These include Bacillus amyloliquefaciens, Bacillus subtilis, Bacillus pumilus, Bacillus cereus and Bacillus anthracis.

From the BLAST result, Bacillus subtilis was identified as the most predominant species during the fermentation of lima bean to produce daddawa (Table 3). Azokpota et al. (2007), who used ITS - PCR - RFLP analysis to identify the bacteria isolated from three daddawa products (iru, afitirin and sonru), reported that Bacillus subtilis group represented the dominant species in the three condiments (iru, afitirin and sonru). Adewunmi et al. (2013) also reported that the result of polymerase chain reaction - denaturing gradient gel electrophoresis (PCR-DGGE) identified Bacillus subtilis as the consistent bacterial species associated with fermentation of iru. Previous studies by several authors using culture dependent methods and biochemical characterization have also reported Bacillus subtilis as being predominant during fermentation of beans to produce

Table 2 Result of the 16SrRNA Squence Analysis of the Bacterial Isolate

\begin{tabular}{|c|c|c|c|c|}
\hline Isolate & Identity & (\%) Similarity & Base sequence & Accession Number \\
\hline 1 & B. amyloliquefaciens Strain FGYM6 & 98 & 1173 & JN999853.1 \\
\hline 2 & B. subtilis Strain ov & 98 & 1196 & GU585579.1 \\
\hline 3 & Bacillus sp. Strain OS 1 & 98 & 1181 & EF428970.1 \\
\hline 4 & B. anthracis Strain R5-331 & 97 & 1120 & JQ65973.1 \\
\hline 5 & B. anthracis Strain yxc1-1 & 97 & 1050 & JF701962.1 \\
\hline 6 & B. subtilis Strain C3 & 95 & 1179 & JX120508.1 \\
\hline 7 & B. cereus Strain 25 & 95 & 1089 & DQ42176.1 \\
\hline 8 & B. subtilis Strain 30L1-2 & 94 & 911 & JN366795.1 \\
\hline 9 & Bacillus sp. Strain EGY-WCP9 & 95 & 1199 & KF5623361.1 \\
\hline 10 & B. subtilis Strain BG-B7 & 97 & 1164 & EU869248 \\
\hline 11 & B. anthracis Strain R5-331 & 97 & 1193 & JQ659732.1 \\
\hline 14 & B. pumilus Strain DL-006 & 98 & 1151 & KJ608548.1 \\
\hline 16 & B. cereus Strain VIT-AVJ & 97 & 1174 & KJ437489.1 \\
\hline 17 & B. amyloliqueficiens & 97 & 1147 & KC492052 \\
\hline 18 & B. cereus Strain $\mathrm{HC} 23$ & 97 & 1175 & KJ206081.1 \\
\hline 19 & Bacillus sp. Strain HB38 & 96 & 1191 & KF8638337.1 \\
\hline 20 & B. cereus Strain 400 & 98 & 1145 & DQ420187.1 \\
\hline 21 & B. amyloliquefaciens Strain D.18 & 98 & 1146 & AB813716.1 \\
\hline 22 & B. amyloliquefaciens Strain NK3-1 & 98 & 1158 & HQ831391.1 \\
\hline 23 & Bacillus. sp. Strain HB38 & 97 & 1171 & KF863837.1 \\
\hline 25 & B. anthracis Strain R5331 & 94 & 1154 & JQ659732.1 \\
\hline 26 & B. subtilis Strain AB30 & 97 & 1142 & JX188065.1 \\
\hline
\end{tabular}

condiments (Antai and Ibrahim, 1986; Odunfa and Oyewole, 1986; N'dir et al., 1994; Omafuvbe et al., 2000; Omafuvbe et al., 2002; Ouoba et al., 2004; Okpara et al., 2013). Bacillus species have been reported to be associated with fermentation of vegetable proteins (Abiose et al., 1986: Kiers et al., 2000;
Omafuvbe et al., 2002; Enujiugha, 2009; Ojinaka and Ojimelukwe, 2013). Inability to identify $15 \%$ of the total isolates could probably be linked with some inadequacies in the nucleotide sequence in the genes of the representative chromosomes with which the primers could bind. Azokpota et al. (2007) also 
reported that $16 \%$ of isolates from iru and sonru (daddawa-like) could not be identified with molecular method.

Bacillus subtilis, Bacillus amyloliquefaciens, Bacillus pumilus were found to occur throughout the fermentation period (Table 4). The occurrence of Bacillus subtilis throughout the fermentation period and its predominance in fermenting beans has been reported by various authors (Ogueke and Ariatu, 2004; Achi, 2005; Omafuvbe, 2008; Adelekan and Nwadiuto, 2012). Bacillus subtilis was identified as the best starter culture for fermentation of soybean to produce daddawa (Omafuvbe et al., 2002). Of particular interest is Bacillus amyloliquefacens which also occur

Table 3 Species of Bacillus identified by 16SrRNA Sequence Analysis Using Basic Local Alignment Search Tool (BLAST)

\begin{tabular}{lll}
\hline Isolate number & \multicolumn{1}{c}{ \% similarity } & \multicolumn{1}{c}{ Bacterial specie } \\
\hline $1,17,21,22$ & $98,98,98$ and 98 respectively & Bacillus amyloliquefaciens \\
$2,6,8,10,26$ & $98,94,94,97$ and 97 respectively & Bacillus subtilis \\
$3,9,19$ and 23 & $98,95,96$ and 97 respectively & Bacillus species \\
14 & 98 & Bacillus pumilus \\
$7,16,18,20$ & $95,97,97$ and 98 respectively & Bacillus cereus \\
$4,5,11,25$ & $97,97,97$ and 94 respectively & Bacillus anthracis \\
$12,13,15$ and 24 & No matched identity & \\
\hline
\end{tabular}

Table 4 Bacterial Succession during Natural Fermentation of Lima Bean to Produce Daddawa

\begin{tabular}{llccc}
\hline \multirow{2}{*}{ Bacteria } & \multicolumn{3}{c}{ Fermentation time (h) } \\
\cline { 2 - 5 } & 0 & 24 & 48 & + \\
\hline Bacillus subtilis & + & + & + \\
B. amyloliquefaciens & + & + & + & + \\
B. pumilus & + & + & - & - \\
B. cereus & + & + & - \\
B. anthracis & + & + & - \\
\hline+ present & - = not present & &
\end{tabular}

through-out the fermentation process. Bacillus amyloliquefaciens is a plant associated bacterium which is known for its ability to promote host plant growth through production of stimulating compounds and suppression of soil borne pathogens by synthesizing antibacterial and antifungal metabolites (Niazi $\boldsymbol{e t}$ al. 2014). Of concern is the occurrence Bacillus cereus and Bacillus anthracis in the fermentation process as their presence in the fermented product could pose public health problems (Adelekan and Nwadiuto, 2012). Occurrence of these organisms did not exceed $24 \mathrm{~h}$ of fermentation, an indication that they are not important in the fermentation of lima bean. Adelekan and Nwadiuto (2012) similarly reported occurrence of Bacillus cereus and Bacillus anthracis during the first $48 \mathrm{~h}$ of fermentation of locust bean to produce daddawa. Bacillus cereus and Bacillus anthracis have been reported to be members of cultivable bacteria associated with fermented beans (Choma and Granum, 2002; Ouoba et al. 2004; Oguntoyinbo et al., 2010).

The occurrence of Bacillus cereus and Bacillus anthracis or any other pathogen in the early stages of fermentation process could probably have arisen from handling of the beans after boiling and their inability to occur at the later stages of fermentation might be due to unfavorable environment for their surviva (Omafuvbe et al., 1999) coupled with the of presence of B. amyloliquefaciens which might probably suppress or inhibit growth of pathogens. However, food borne diseases have not been reported in areas where these condiments (iru/daddawa, afitirin, soniru) are generally consumed (Azokpota et al., 2007). Azokpota et al. (2007) thus suggested that further medical investigation have to be carried out to confirm whether Bacillus cereus strains identified in fermented condiments such as iru/daddawa are actually toxigenic.

There were no fungi isolated in the Lima bean fermentation process. This might be as a result of heat process prior to fermentation and probably an uncondusive environment for their growth and multiplication. Absence of fungi in the fermented Lima beans makes the product safe for consumption in terms of mycotoxin production (Abiose et al., 1986).

\section{CONCLUSION}

The study concluded that molecular method could be used to identify the important microorganisms in fermentation of lima bean to produce daddawa. The method revealed that Bacillus subtilis, B. pumilus and B.amyloliquefaciens were majorly involved in the fermentation process with $B$. subtilis been predominant and that these three species of Bacillus could be tested and purified for use as potential starter for producing quality lima bean daddawa.

\section{REFERENCES}

Abiose, S. H., Atalabi, T. A. \& Ajayi, L. O. (1986). Fermentation of African Locust beans: Microbiological and Biochemical Studies. Nigerian Journal of Biological Sciences, 1(2), 109- 114.

Achi, O. K. (2005). Traditional fermented protein condiments in Nigeria. African Journal of Biotechnology, 4(13), 1612-1621.
Achi, O. K. (1992). Microorganisms associated with natural fermentation of Prosopis africana seeds for the production of okpiye. Plant Foods Human Nutrition, 42, 297-304.

Adelekan, A. O. \& Nwadiuto, E. (2012). Bacterial Succession Studies during fermentation of African Locust Bean (Parkia biglobosa) to Iru using molecular methods. British Biotechnology Journal, 2(1), 49-59.

Adewunmi, G. A., Oguntoyinbo, F. A., Keisam, S., Romi, W. \& Jeraham, K. (2013). Combination of culture independent and culture dependent molecular methods for the determination of bacterial community of iru a fermented Parkia

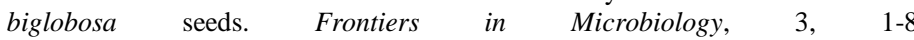
http://dx.doi.org/10.3389/fmicb.2012.00436

Altschul, S. F., Thomas, M. L., Alejandro, S. A., Jinghui, Z., Zheng, Z. \& Webb M. (1997). Gapped BLAST and Psi- BLAST, a new generation of protein database search programs. Nucleic acid Research, 25, 3389-3402.

Antai, S. P. and Ibrahim, M. H. (1986). Microorganisms associated with African locust bean (Parkia filicoidea)) fermentation for daddawa production. Journal of Applied Bacteriology $145-148$

Ash, C., Farrow, J. A. E., Wallbanks, S. \& Collins, M. D. (1992). Phylogenetic heterogeneity of the genus Bacillus revealed by comparative analysis of small subunit ribosomal RNA sequences. Letters of applied Microbiology, 13, 202-206. Azokpota, P., Moller, P. L., Hounhoungan, J. D. \& Jakobsen, M. (2007). Biodiversity of predominant Bacillus isolated from afitirin, iru and sonru at different fermentation time. International Journal of Biological and Chemical Science, 1(3), 211-222.

Barber, L., Achinewhu, S. C. \& Ibiama, E. M. (1988). The microbiology of ogiri production from castor seeds (Ricinus communs). Food Microbiology, 5 , 177-182.

Barimalaa, I. S., Achinewu, S. C., Yiutana, I. \& Amadi, E. N. (1994). Studies on the solid substrate fermentation of Bambara groundnut. Science Food Agriculture, 66, 443-453.

Biobank (2004). http://www.ukbiobank.ac.uk/scientists Date retrieved: 16-092015.

Brown, T. A. (1993). Gene cloning. Chapman and Hall. 2-6 Boundary Row, London

Choma, C. \& Granum, P. E. (2002). The enterotoxin T (BcET) from Bacillus cereus can possibly contribute to food poisoning. FEMS Microbiology Letters, 217, 115-1119.

Cocolin, L. \& Ercolini, D. (2009). Microbiology of food fermentation. The support of molecular techniques. Scitropics. http://www.scitropics.com/microbiology of food fermentation the support of molecular techniques.html Date retrieved: 14-0615 .

Egwim, E., Amanabosa, M., Yahaya, A. \& Bello, M. (2013). Mycotoxins and Food Safety in Developing Countries In: Nigerian Indigenous Fermented Foods, processes and prospects. INTECH Open Science, 154-180.

Elemo G. N., Elemo B. O., Oladunmoye O. O. \& Erukainure O. L. (2011). Comprehensive investigation into the nutritional composition of dehulled and defatted African locust bean seed (Parkia biglobosa). African Journal of Plant Science, 5(5), 291-295. 
Enujiugha, V. N. (2009). Major fermentative organisms in some Nigerian soup condiments. Pakistan Journal of Nutrition, 8, 279-283.

Enujiugha, V. N., Akanbi, C.T. \& Adeniran, H. A. (2008). Evaluation of starters for fermentation of African oil bean (Pentaclethra macrophylla Benth) seeds. Nutrition and Food Science, 38(5), 451-456.

Fadahunsi, I. F. \& Olubunmi, P. D. (2010). Microbiological and enzymatic studies during the development of an iru (a local Nigerian Indigenous fermented condiment from bambara nut (Voandzeia subterranean). Malaysian Journal of Microbiology, 6(2), 123-126.

Farinde, E. O., Adeniran, H. A. \& Abiose, S. H. (2014). Comparative microbial assessment of fermented Lima bean (Phaseolus lunatus) and Locust bean (Parkia biglobosa) in production of Daddawa. British Microbial Research Journal, 4(7), 772-784.

Farinde, E. O., Adeniran, H. A. \& Abiose, S. H. (2011). Proximate composition, mineral content and sensory assessment of an iru analogue produced from lima bean (Phaseolus lunatus). Ife Journal of Technology, 20(2), 1-6.

Fleet, G. H. (1999). Microorganisms in food ecosystems. International Journal of Food Microbiology, 50, 101-117.

Harrigan, W. F. (1998). Laboratory Methods in Food and Dairy Microbiology Academic Press, New York.

Harrigan, W. F. \& McCance, M.E. (1976). Laboratory Methods in Food and Dairy Microbiology Academic Press New York.

Joung, K. B. \& Cote, J. C. (2002). Evaluation of ribosomal RNA gene restriction patterns for the classification of Bacillus species and related general. Journal of Applied Microbiology, 92, 97 - 108.

Kesmen, Z., Yetiman, A. E., Gulluce, A., Kacmaz, N., Sagdic, O. \& Cetin, B. (2012). Combination of culture-dependent and culture-independent molecular methods for the determination of lactic microbiota in sucuk International.Journal of Food Microbiology, 153, 428-435. http://dx.doi.org/10.1016/j.ijfoodmicro.2011.12.008

Kiers, J. L., VanLaekan, A. E. A., Rombouts, F. M. \& Nout, M. J. R. (2000). In vitro digestibility of Bacillus fermented soya bean. International Journal of Food Microbiology, 60, 163-169.

Kolbert, C. P. \& Persing, D. H. (1999). Ribosomal DNA sequencing as a tool for identification of bacterial pathogens. Current opinion in Microbiology, 3, 299305. http://dx.doi.org/10.1016/S1369-5274(99)80052-6

Leninger, A. L. (1975). Thermo Scientific T009 Technical Bulletin. Biochemistry $2^{\text {nd }}$ edition, Worth Publishers, New York.

Liu, P. Y. F. \& Chen, S. L. (1997). Use of Pulse Field Gel Electrophoresis to investigate pseudo-outbreak of B. cereus in a Pediatric unit. Journal of clinical Microbiology, 35,1533-1535.

Morten, P., Smalla, K. \& Berg, G. (2000). Genotypic and phenotypic differentiation of an antifungi biocontrol strain belonging to Bacillus subtilis. Journal of Applied Microbiology, 89, 463-471.

Mendo, A. L. V., Henriques, S. I., Correia, C. M. A. \& Duarte, M. C. J. (2000) Genetic characterization of a new thermotolerant Bacillus licheniformis strain. Current Microbiology, 40, 137-139.

Miabi, E., Guyot, J. P. \& Ampe, F. (2003). Identification, isolation and quantification of representative bacteria from fermented cassava dough using an intergrate approach of culture- dependent and culture-independent methods. International Journal of Food Microbiology, 82, 111-120.

Niazi, A., Manzoor, S., Bejai, S., Meijer, J. \& Bongcam-Rudloff, E. (2014) Complete genome sequence of a plant associated bacterium Bacillus amyloliquefaciens subsp. Plantarum UCMB5033. Standards in Genomic Sciences, 9, 718-725. http://dx.doi.org/10.4056/siqs.4758653

N'Dir, B., Hbid, C. L., Cornelius, C., Roblain, D., Jacques, P. \& Vanhentenryck F. (1994). Proptiétés antifongiquesdela microflora sporuléedunététu. Report International 9, 453-456.

Odunfa, S. A. \& Oyewole, O. B. (19860. Identification of Bacillus Species from iru, a fermented African locust bean product. Journal of Basic Microbiology, 26 , 101-106.

Ogueke, C. C. \& Ariatu, L. E. (2004). Microbial and organoleptic changes associated with Ugba stored at ambient temperature. Nigerian Food Journal, 22, 133-140. http://dx.doi.org/10.4314/nifoj.v22:1.33578

Oguntoyinbo, F. A., Huch, M., Cho, G., Schillinger, U., Holzappfel, W.H., Sanni, A.I. \& Frannz, C. M. (2010). Diversity of Bacillus Specie isolated from Okpehe, a traditional fermented soup condiment from Nigeria. Journal of Food Protection, 73, 870-878.

Ojinaka. M. C. \& Ojimelukwe, P. C. (2013). An assessment of the microbial and amino acid contents of ogiri produced by fermenting oil bean seeds of Ricinus commumis. American Journal of Food and Nutrition, 3 (3), 155-161 http://dx.doi.org/10.5251/ajfn.2013.3.3.155.161.

Okpara, C. N., Okolie, P. I. and Uzochukwu, S. V. (2013). Diversity of Bacterial community in fermentation of African oil bean seeds (Pentaciethra macrophylla Benth) by comparison of 16SrRNA gene fragments. British Biotechnology Journal 3(2): 213-220.

Omafuvbe, B. O. (2008). Effect of temperature on biochemical changes induced by Bacillus subtilis (SDA3) during starter culture fermentation of soybean into condiment. American Journal of Food Technology 3(1): 33 - 41.
Omafuvbe, B. O., Falade, O. S., Osuntogun, B. A.and Adewusi, S. R. A. (2004) Chemical and biochemical changes in African locust bean (Parkia biglobosa) and melon (Citrullus vulgaris) seeds during fermentation to condiments. Pakistan Journal of Nutrition 3: 140 - 145 .

Omafuvbe, B. O., Abiose, S. H. \& Shonukan. O. O. (2002). Fermentation of Soydadawa (Glycine max) for soy-daddawa production by starter culture of Bacillus. Food Microbiology, 19, 561-566. http://dx.doi.org/10.1006/yfmic.513

Omafuvbe, B. O., Shonukan, O. O. \& Abiose, S. H. (2000). Miocrobiological and biochemical changes in the traditional fermentation of soybean for soy daddawa, Nigerian fermented condiment. Food Microbiology, 17, 469-474.

Omafuvbe, B. O., Abiose, S. H. \& Adaraloye, O. O. (1999). The production of Kpaye a fermented condiment from Prosopis africana (Guill and Perr) Taub. Seeds. International. Journal of Food Microbiology, 51, 183-186.

Ouba, L. I., Dawara, B., Amoa-Awua, W. K., Traore, A. S. \& Moller, P. 1 (2004). Genotyping of starter cultures of B. subtilis and B. pumilus for fermentation of African Locust bean (parkia biglobosa) to produce Soumbala. International Journal of Food Microbiology, 90 (2), 197-205.

W. H. Foods. (2010). Limabeans. http://www. whfoods.com/genpage.php?tname=foodspice $\$ d b i d=59$. Date retrieved: $14-06-14$

Yellavila, S.B., Agbenorhevi, J.K., Asibuo, J.Y. \& Sampson, G.O. (2015), "Proximate

composition, mineral content and functional properties of 5 Lima bean Acessions'. Journal of Food Security, 3(3), 69-74. http://dx.doi.org/10.12691/jfs$\underline{3-3-1}$ 